http://dx.doi.org/10.1590/1678-4162-8848

Arq. Bras. Med. Vet. Zootec., v.68, n.4, p.825-831, 2016

\title{
Biometrics of hoof balance in equids
}

\author{
[Biometria do equilíbrio podal de equídeos]

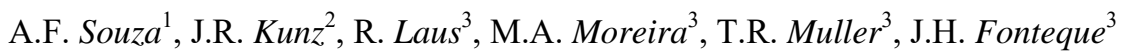 \\ ${ }^{1}$ Aluno de graduação - Universidade do Estado de Santa Catarina - Lages, SC \\ ${ }^{2}$ Aluno de pós-graduação - Universidade do Estado de Santa Catarina - Lages, SC \\ ${ }^{3}$ Universidade do Estado de Santa Catarina - Lages, SC
}

\begin{abstract}
Differences in hoof balance between horses, mules and donkeys were identified in order to form more specific considerations for proper management of the animals. Measurements of the natural dimensions of hooves in sixty animals were used: 20 horses from the Crioulo breed, 20 mules and 20 donkeys from the Pêga breed. Liveweight was estimated using the correlation equations in each species by heart girth. Using a caliper rule, tape measure and hoof gauge, measurements of the length and width of the frog, hoof height, angle of heel, medial and lateral dorsal length, angle of the toe and crown circumference of the hooves of forelimbs and hindlimb were taken. Within each group the hooves of the hindlimbs exhibited narrower measurements than the hooves of the forelimbs and no difference was observed between the hoof angle of both members of groups. The conformation of the hooves of donkeys is shown to be substantially different from that observed in horses, the mules being in an intermediate condition, being smaller, angled and robust frog and proportionally more developed. Similarly, the hooves of donkeys provide greater support area compared to mules and horses, in descending order, even being dimensionally smaller. We conclude that the hooves of horses, mules and donkeys, have specific patterns of geometric balance that must be taken into consideration at the time of trimming and imbalance inferences.
\end{abstract}

Keywords: equine, mules, donkeys, hoof, shoeing

\section{RESUMO}

O objetivo deste trabalho foi determinar o equilíbrio dos cascos de equídeos. Foram utilizados 60 animais, sendo estes: 20 equinos da raça Crioula, 20 muares e 20 asininos da raça Pêga. O peso vivo foi estimado por meio de equações de correlação com o perímetro torácico específico a cada espécie. Utilizando-se paquímetro, fita métrica e podogoniômetro, foram mensurados comprimento e largura da ranilha e do casco, altura e ângulo dos talões medial e lateral, comprimento dorsal e ângulo da pinça e perímetro da banda coronária dos cascos dos membros torácicos e pélvicos. Dentro de cada grupo, observou-se que os cascos dos membros pélvicos exibem-se mais estreitos que os cascos dos membros torácicos, e não houve diferença entre o ângulo das pinças de ambos os grupos de membros. A conformação dos cascos dos asininos mostra-se substancialmente divergente do observado nos equinos, estando os muares numa condição intermediária, sendo aqueles menores, mais angulados e com ranilha robusta e proporcionalmente mais desenvolvida. Da mesma forma, os cascos dos asininos proporcionam maior área de apoio em relação aos muares e equinos, em ordem decrescente, mesmo sendo dimensionalmente menores. Conclui-se que os cascos de equinos, muares e asininos apresentam padrões de equilíbrio geométrico específicos, que devem ser levados em consideração no momento do casqueamento e na inferência de desequilíbrios.

Palavras-chave: equino, muares, asininos, casco, casqueamento

Recebido em 29 de outubro de 2015

Aceito em 10 de dezembro de 2015

E-mail: anderson.sji@hotmail.com 


\section{INTRODUCTION}

The guidelines of proper hoof trimming are based on observations of the way the hoof is shaped and its adaptation to the pattern of movement carried out by the individual (Davies et al., 2007; Stashak, 2006). Besides genetic orietation, the hoof conformation changes due to variations in the environment, type of pace, nutrition and a large portion of management to which the hooves are subjected, therefore variations within the same species and even more remarkable in different species within the same genus can be identified due to these variables. Classically, the genus Equus had anatomophysiological compensatory adaptations (Senior, 2013; Grosenbaugh et al., 2011), and among them foot balance (Burnham, 2002).

Historically, mules and donkeys showed enormous contribution to the development of civilizations, with extensive use in various tasks, especially those related to traction, due to its rustic features and great adaptability to different environmental conditions (Clutton-Brock et al., 1992). With the evolution of mechanical engineering the equide was directed to leisure and competition, and horses began to have immense economic value (Grosenbaugh et al., 2011). Scientific research was mainly directed to horses and often extrapolating for other species such as mules and donkeys, which can often be a mistake (Senior, 2013; Burnham, 2002).

Even with clear differences in conformation of the hooves of different equides, the farrier may often establish adjustments based on subjective inferences from the widespread knowledge about horses, which can lead to disastrous consequences in the locomotion of the mules and donkeys. To this end, it is necessary to investigate and to determine the differences in hoof characteristics between these groups of animals in order to make specific recommendations, since the current literature is lacking in foot balance approach for donkeys and mules.

The aim of this study is to identify differences in hoof balance between horses, mules and donkeys, in order to create a more specific and proper management of the hooves of these animals.

\section{MATERIALS E METHODS}

The animal use met the requirements of the Santa Catarina State University Animal Ethics Committee $\left(\mathrm{n}^{\circ}\right.$ 01.05.13). Animal owners gave consent for their inclusion in the study.

The hooves of fore and hindlimbs from 60 equids were measured, divided into three groups; 20 horses from the Crioulo breed, with mean age of $8.3 \pm 5.0$ years and mean liveweight of $425.32 \pm 45.47 \mathrm{~kg}, 65 \%$ (13 animals) were females and $35 \%$ (seven animals) were males; 20 mules, from crosses predominantly among asses from the Pêga breed with mares of theThoroughbred or Mangalarga Marchador breeds, with mean age of $6.2 \pm 2.3$ years and mean liveweight of $284.82 \pm 31.20 \mathrm{~kg}$, being $75 \% \quad(15$ animals $)$ females and $25 \%$ (five animals) males, and 20 Pêga donkeys with a mean age of $8.7 \pm 8.5$ years and mean liveweight of $218.97 \pm 37.83 \mathrm{~kg}, 60 \%$ (12 animals) females and 40\% (eight animals) males. All animals were unshod and with adequate foot conformation, kept in a semiextensive system and feed with natural pasture, hay and ryegrass Tifton, mineral salt, commercial concentrated feed and water ad libitum.

The evaluation of the particulars of the measurement of the hooves was made according to descriptions by Turner (1992), Lazzeri (1992) and Melo et al. (2006), the use of a caliper rule, tape measure and hoof gauge. The measured parameters were: length and width of the hoof, medial and lateral height of heel, toe length, hoof angle, angles of the lateral and medial heel, width and length of the hoof and crown circumference. The weight of the equine was estimated using a tape correlation between the liveweight and heart girth, which takes into account the equation: heart girth $(\mathrm{m})^{3} \times 80$. The estimated liveweight of mules and donkeys was performed using correlation equations: ((heart girth $(\mathrm{cm}) \times 3.57)-292)$ and heart girth $(\mathrm{cm})^{2.65} /$ 2188, proposed by Kay et al. (2004) and Pearson and Ouassat (1996), respectively. The relationship between liveweight and the area of the hoof to evaluate the size of the hoof to the animal's weight was carried out using the formula ([liveweight $\mathrm{x}$ 12,56] / crown circumference $^{2}$ ) (Turner, 2003) 
$T$ test was used to compare the averages within each group and ANOVA followed by Tukey's test was performed for comparisons between groups, with $\mathrm{P}<0.05$. The Pearson's correlation was used to assess the liveweight across the back toe length and the crown circumference.

\section{RESULTS}

Means and standard deviations of the 11 variables measured for forelimbs and hindlimbs of horses, mules and donkeys are shown in Table 1.

Comparisons of measurements between members within each group showed significantly lower differences in the heights of the medial heel and sides and the width of the sole and the largest width of the hoof of the hindlimbs in all groups. The angles of the medial heel and lateral heels were smaller in hind limbs in horses and mules, and in these, the angle of the medial bead showed only numerical difference. The mules exhibit longer frog in the forelimbs accompanied by greater length of the sole. The donkeys have smaller crown circumference of the hind limbs. There was no difference between the angles and dorsal toe length in all evaluated groups.

In comparisons between groups for the forelimbs there were significant differences in the length of the frog, heights of the medial and lateral heel, width of the sole and the crown circumference in descending order respectively for horses, mules and donkeys $(\mathrm{p}<0.0001)$. The width of the frog was lower in mules $(\mathrm{P}<0.0001)$, toe length $(\mathrm{P}<0.0001)$, and the length of the sole were lower in donkeys $(\mathrm{P}<0.0001)$ which had greater caliper angles and medial heel and sides $(\mathrm{P}<0.0001)$. These variables showed no significant differences in the underlying groups.

The hindlimbs, the variables length of the frog, length and width of the sole and the crown circumference also showed decreasing significant differences for horses, mules and donkeys in this order $(\mathrm{P}<0.0001)$. Conversely there was the same configuration as the hoof angle, being consistently higher for donkeys $(\mathrm{P}<0.0001)$. The width of the frog was also lower in mules $(\mathrm{P}=0.0018)$ and horses had greater heights at medial heel $(\mathrm{P}=0.0172)$ and side $(\mathrm{P}<0.0001)$, and the angle was larger in donkeys $(\mathrm{P}<0.0001)$, which also exhibited lower toe length $(\mathrm{P}<0.0001)$.

The relationship between liveweight and the area of the hoof reported to be $4.71 \pm 0.47 \mathrm{~kg} / \mathrm{cm}^{2}$, $3.75 \pm 0.41 \mathrm{~kg} / \mathrm{cm}^{2}$ and $3.35 \pm 0.46 \mathrm{~kg} / \mathrm{cm}^{2}$, for horses, mules and donkeys, respectively. This revealed that the donkeys have a larger support area, which gives them more support in rustic to hostile surfaces. A moderate correlation between toe length and the liveweight on the mules $(0.66)$ and weak for horses (0.28) and donkeys (0.30) was identified. The correlation of liveweight to the crown circumference reported to be 0.43 , 0.58 and 0.66 in mules to horses and donkeys, respectively.

Table 1. Means and standard deviations of measurements of the hooves for fore and hindlimbs of horses from the Crioulo breed $(n=20)$, mules $(n=20)$, and the Pêga breed donkeys $(n=20)$

\begin{tabular}{|c|c|c|c|c|c|c|}
\hline \multirow[b]{2}{*}{ Measurements } & \multicolumn{2}{|c|}{-------- Horses -------- } & \multicolumn{2}{|c|}{------- Mules -------- } & \multicolumn{2}{|c|}{------ Donkeys ------- } \\
\hline & Forelimb & Hindlimb & Forelimb & Hindlimb & Forelimb & Hindlimb \\
\hline Frog's length $(\mathrm{cm})$ & $8.31 \pm 0.71 \mathrm{Aa}$ & $8.30 \pm 0.68 \mathrm{Aa}$ & $7.83 \pm 0,68 \mathrm{Ba}$ & $7.37 \pm 0.61 \mathrm{Bb}$ & $6.30 \pm 0.81 \mathrm{Ca}$ & $6.03 \pm 0.67 \mathrm{Ca}$ \\
\hline Medial heel length $(\mathrm{cm})$ & $5.04 \pm 0.53 \mathrm{Aa}$ & $4.35 \pm 0.58 \mathrm{Ab}$ & $4.66 \pm 0,54 \mathrm{Ba}$ & $4.10 \pm 0.39 \mathrm{ABb}$ & $4.36 \pm 0.60 \mathrm{Ca}$ & $4.02 \pm 0.56 \mathrm{Bb}$ \\
\hline Lateral heel length $(\mathrm{cm})$ & $5.07 \pm 0.52 \mathrm{Aa}$ & $4.33 \pm 0.52 \mathrm{Ab}$ & $4.75 \pm 0,58 \mathrm{Ba}$ & $3.91 \pm 0.47 \mathrm{Bb}$ & $4.42 \pm 0.55 \mathrm{Ca}$ & $3.73 \pm 0.59 \mathrm{Bb}$ \\
\hline Toe length $(\mathrm{cm})$ & $8.59 \pm 0.69 \mathrm{Aa}$ & $8.64 \pm 0.57 \mathrm{Aa}$ & $8.46 \pm 0,79 \mathrm{Aa}$ & $8.53 \pm 0.90 \mathrm{Aa}$ & $7.47 \pm 0.86 \mathrm{Ba}$ & $7.70 \pm 0.67 \mathrm{Ba}$ \\
\hline Medial heel angle $\left({ }^{\circ}\right)$ & $45.50 \pm 4.09 \mathrm{Ba}$ & $42.71 \pm 3.50 \mathrm{Bb}$ & $45.08 \pm 6,21 \mathrm{Ba}$ & $43.80 \pm 6.02 \mathrm{Ba}$ & $52.63 \pm 6.38 \mathrm{Aa}$ & $51.70 \pm 6.82 \mathrm{Aa}$ \\
\hline Hoof width $(\mathrm{cm})$ & $11.69 \pm 0.58 \mathrm{Aa}$ & $11.26 \pm 0.60 \mathrm{Ab}$ & $9.33 \pm 0,64 \mathrm{Ba}$ & $8.81 \pm 0.68 \mathrm{Bb}$ & $8.32 \pm 0.76 \mathrm{Ca}$ & $7.58 \pm 0.52 \mathrm{Cb}$ \\
\hline Hoof length $(\mathrm{cm})$ & $12.91 \pm 0.68 \mathrm{Aa}$ & $12.79 \pm 0.60 \mathrm{Aa}$ & $12.90 \pm 1,07 \mathrm{Aa}$ & $12.30 \pm 1.00 \mathrm{Bb}$ & $10.87 \pm 1.06 \mathrm{Ba}$ & $10.42 \pm 1.02 \mathrm{Ca}$ \\
\hline $\begin{array}{l}\text { Crown circumference } \\
(\mathrm{cm})\end{array}$ & $33.89 \pm 1.12 \mathrm{Aa}$ & $33.47 \pm 1.15 \mathrm{Aa}$ & $31.12 \pm 1,97 \mathrm{Ba}$ & $30.74 \pm 2.09 \mathrm{Ba}$ & $29.04 \pm 1.55 \mathrm{Ca}$ & $28.16 \pm 1.57 \mathrm{Cb}$ \\
\hline
\end{tabular}

Averages followed by the same upper case letter between groups and lower case letter within a group do not differ by the Tukey test $(\mathrm{P}<0.05)$. 


\section{DISCUSSION}

Extreme caution in interpreting results must be taken when using mules as an experimental model because they present strong anatomical and physiological differences due to genetic variance (Burham, 2002). There is a strong correlation between the size of the hoof and the animal's size (Melo et al., 2006). In order to minimize these effects and enable statistical analysis between groups in this work, the formation of groups was based on the closest similarity of body structure.

Analyzing hoof arquitecture, it is observed that all groups showed more rounded hooves of forelimbs, justified by the greater width of the hoof accompanied closely by frog. In contrast, the hooves of the hindlimbs showed more oval conformation due to smaller width culminating in a larger base of the frog. These results agree with the statements of Stashak (2006) and Dyce et al., (1997) which incriminate the location of the center of gravity of the forelimbs associated with support of about $60-65 \%$ of liveweight of the animal, generating greater impact during locomotion, facilitating the expansion of hooves compared to the hindlimbs.

There was a lack of parallelism of the guidelines for angles between the toe and heels in all groups, wherein the heels had average values greater than the margin commonly regarded as ideal, a variation up to five degrees in relation to the hoof angle (Turner, 2003). This difference comes from heel's lengths lugs having a third of the toe length as ideal as described by Lazzeri (1992) and Turner (2003). The magnitude of these differences was higher in donkeys, followed by mules. A more accurate visual analysis identifies that the donkeys had the angular relationship hoof:pastern prone to positive, with the base of the frog surpassing the points marked by the medial angles and side of the sole and with a higher width:length ratio, making it possible to promote greater frog contact ability with the ground and can be a cause or a consequence of a possible palmar/plantar position more poportional to the center of gravity in relation to the set in horses with even greater verticalisation of the hoof (Figure 1).

The center of gravity in the equine hoof, also known as Duckett's Dot, is located in the palmar/plantar true apex of the frog at about 0.95 to $1.90 \mathrm{~cm}$, and under it is the insertion point of the deep digital flexor tendon on the surface flexion of the distal phalanx (Sampaio et al., 2014).

Establishing the length: breadth of the hoof, it is observed that this is higher in donkeys and mules, just by measuring regardless of the base of the frog, which in these animals protrudes more palmar/plantar. Associated with a larger width thereof, which leads to a higher relation with the soil, which may have more oblique conformation contribution to the heels. Whereas the frog has, among other functions, to act as a buffer component of the impact on the hooves and assist as driver of vascular return (Andrade, 1986; Stashak, 2006), that more robust configuration gives the animals more adequacy when exposed to surfaces that offer greater impact.

The hoof angle has intrinsic influence on the trajectory and landing of the hoof. In smaller angle conditions there is a tendency to support primarily the dorsal portions of the hoof, and the opposite is also true (Stashak, 2006). Thus the donkeys, since they expose much more upright hooves, tend to have a natural shortening of the cranial stage as well as the entire arch and require an increased number of steps to move through the same distance when compared to a horse with straight foot-pastern axis. The angle also influences the graft in digit, and the higher the lowest angle graft. The hoof angle also influences the impact of the digit, and the higher the lowest angle impact (Frandson et al., 1978; Clayton, 1987; Barey, 1990).

The establishment of the most appropriate hoof angle of the horse is much discussed (Bushe et al., 1987; Stashak, 2006; Andrade, 1986). This essentially depends on the conformation and activity performed by the animal, presenting variations between the fore and hindlimbs. Angulation of $45^{\circ}$ to $50^{\circ}$ forelimbs and $50^{\circ}$ to $55^{\circ}$ for pelvic, were believed for a long time, but now it is known that they are not suitable. Such a determination must be made individually, taking into account the whole conformation of the distal member portion, with greater attention to orientation of the pastern (Melo et al., 2006; Balch et al., 1995). 


\section{Biometrics of...}

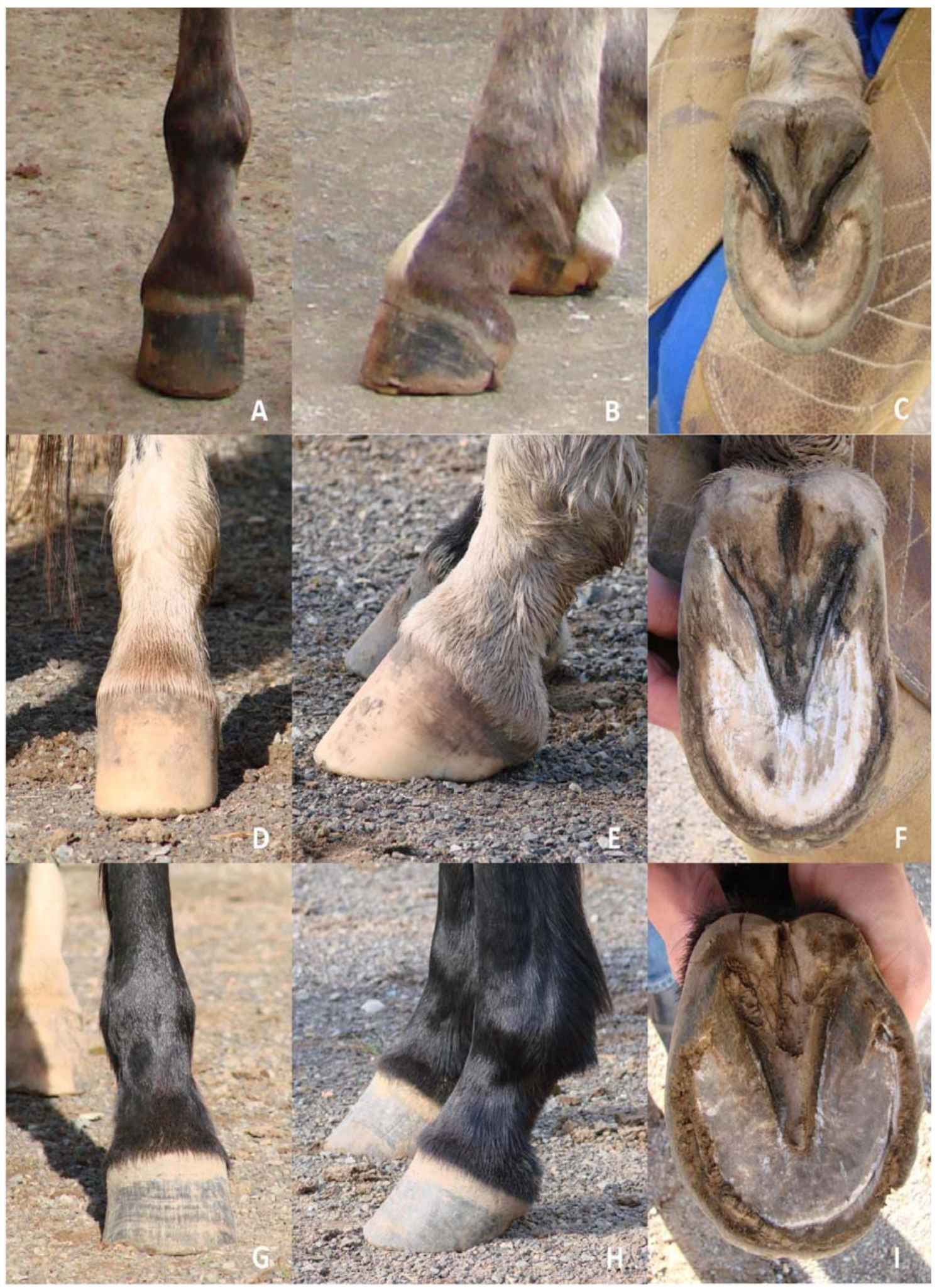

Figure 1. Respective dorsal, lateral and solear views of donkey hooves (A, B and C) mule (D, E and F) and horse $(\mathrm{G}, \mathrm{H}$ and $\mathrm{I})$. Obvious differences are observed in the structure and proportions of the different component parts of the hoof. 
Observations of foot characteristics of horses living in natural conditions show values hoof angles around $54^{\circ}$, which seems to be the most suitable; lower values cause high stress on the flexor apparatus, with various pathological effects, and predisposes the heel's contracture and delayed breakover (Melo et al., 2006). Higher values do not seem to be as problematic if they can lead to suspensory apparatus diseases. A recent study of wild horses showed a mean of $52.8 \pm 2.6^{\circ}$ in the forelimbs (Hampson et al., 2013).

Available foot support area is a relentlessly important factor in the health and capacity of the foot, but little discussed among professionals. The values obtained for the mule largely explains the low occurrence of foot problems, presented by larger area. According to the description by Turner (1992), for values above $5.5 \mathrm{~kg} / \mathrm{m}^{2}$ or 78 $\mathrm{lb} /$ inch $^{2}$ the hoof is considered small, a common problem in animals of Quarter Horses, and it can be a cause or aggravating factor in cases of lameness. Values that are above this limit must receive the recommendation to reduce liveweight and/or the application of measures that promote the expansion of the hoof. Studies have shown the influence of different hoof shapes on the weight forces applied to the capsule and its deep structures (Mcclinchey et al., 2003; Thomason, 1998). A proper estimate of the liveweight is crucial for that assessment. Stachurska et al., (2011) discussed the inaccuracy of the methods of estimating the equine liveweight through correlations with heart girth, based on variations in body conformation that different breeds may have when in the same weight, such effect must be considered when performing similar comparisons. In the present work, the composition of groups per equivalent animal body structure, besides the use of appropriate equations for each group, minimized this effect.

A relationship between the toe length and the liveweight was proposed by Balch et al. (1991), which limits the maximum toe length according to the weight category. This assessment is more striking in mules, with moderate correlation, which is weak for horses and donkeys. This parameter is intended to serve as a guide for trimming the hoof in horses and not to infer in factors that can influence the capsule growth. There was a more suitable interrelation of weight with the crown circumference, which in all groups obtained moderate positive correlation. Decurnex et al. (2009) investigated the training effect of crown circumference in young Thoroughbred horses, noting that there is a downward trend circumference when training with consequent expansion when kept at rest. All animals used in this study had similar activity conditions, and this effect is ignored.

The scope of the perfect harmony static and dynamic hooves is virtually impossible due to the complexity of locomotion, the interactions between structures that involve the distal equine digit associated with environmental influences, as well as the individual variations.

\section{CONCLUSIONS}

There is marked difference in the balance of the hooves of horses, mules and donkeys, with donkeys presenting more upright hooves, with more robust frog and a larger area of support in relation to horses and as expected, the mules are an intermediate condition, confirming the misconduct of adopting the trimming parameters established for horses in donkeys and mules. Therefore, studies for specific knowledge training for proper evaluation and imbalances of inferences that can form solid guidelines for proper trimming of hooves in these species are needed.

\section{REFERENCES}

ANDRADE, L. S. O condicionamento do equino no Brasil. Recife: Equicenter, 1986. 201 p

BALCH, O.; BUTLER, D.; WHITE, K; METCALF, $\mathrm{S}$. Hoof balance and lameness -improper toe length, hoof angle, and mediolateral balance. Comp. Cont. Educ. Pract. Vet., v.17, p.1275-1283. 1995.

BALCH, O.; WHITE, K.; BUTLER, D. Factors involved in the balancing of equine hooves. J. Am. Vet. Med. Assoc., v.198, p.1980-1989, 1991.

BARREY, E. Investigation of the vertical hoof force distribution in the equine forelimb with an instrumented horseboot. Equine Vet. J., v.22, supl. 9, p.35-38, 1990.

BURNHAM, S. L. Anatomical differences of the donkey and mule. In: ANNUAL CONVENTION OF THE AMERICAN ASSOCIATION OF EQUINE PRACTITIONERS, 48., Orlando, Flórida, 2002. Proceedings... [s.1.]: AAEP, 2002. p.102-109. 
BUSHE, T.; TURNER, T.; POULOS, P.; HARWELL, N.M. The effect of hoof angle on coffin, pastern, and fetlock joint angles. In: ANNUAL CONVENTION OF THE AMERICAN ASSOCIATION OF EQUINE PRACTITIONERS, 33. Proceedings..., [s.1.]: AAEP, 1987. p.729-737.

CLAYTON, H.M. Comparison of the stride of trotting horses trimmed with a normal and a broken back hoofpastern axis. In: ANNUAL CONVENTION OF THE AMERICAN ASSOCIATION OF EQUINE PRACTITIONERS, 33. Proceedings..., [s.1.]: AAEP, 1987. p.289-298.

CLUTTON-BROCK, J. Horse power: history of the horse and the donkey in human societies. Massachusetts: Harvard University Press., 1992.

DAVIES, H. M.; MERRITT, J.; THOMASON, J. Biomechanics of the equine foot. In: FLOYD, A. E.; MANSMANN R. Equine podiatry. Missouri: Saunders,. 2007, p.42-53.

DECURNEX, V.; ANDERSON, G.A.; DAVIES, H.M.S. Influence of different exercise regimes on the proximal hoof circumference in young Thoroughbred horses. Equine Vet. J., v.41, p.233-236, 2009.

DYCE, K.M.; SACK, W.O.; WENSING, C.J.G. Tratado de anatomia veterinária. 3.ed. Rio de Janeiro: Guanabara Koogan, 1997, p.446-475.

FRANSDON, R.D.; LEBEL, J.L.; SLADE, C.M.; BARBALANCE, R.C. Effect of slope of equine hoof on concussion and phalangeal angulation. Am. Farrier's J., p.72-73, 1978.

GROSENBAUGH, D.A.; HOOD, D.M. Keratin and associated proteins of the equine hoof wall. Am. J. Vet. Res., v.53, p.1859-1863, 1992.

GROSENBAUGH, D.A.; REINEMEYER, C.R.; FIGUEIREDO, M.D. Pharmacology and therapeutics in donkeys. Equine Vet. Educ., v.23, p.523-530, 2011.

HAMPSON, B.; DE LAAT, M.; MILLS, P.; POLLITT, C.C. The feral horse foot. Part A: observational study of the effect of environment on the morphometrics of the feet of 100 Australian feral horses. Aust. Vet. J., v.91, p.14-22, 2013.
KAY, G.; PEARSON, R.A.; OUASSAT, M. Estimation of the liveweight of working mules in Morocco from their body measurements. Vet. Rec., V.154, p.85-88, 2004.

LAZZERI, L. Lições de podologia equina. Belo Horizonte EV-UFMG,. 1992, 224p.

MCCLINCHEY, H.L.; THOMASON, J.J.; JOFRIET, J.C. Isolating the effects of equine hoof shape measurements on capsule strain with finite element analysis. Vet. Comp. Orthop. Traumatol., v.16, p.6775, 2003.

MELO, U.P.D.; FERREIRA, C.; SANTIAGO, R.M.F.W. et al. Equilíbrio do casco eqüino: uma revisão. Cienc. Anim. Bras., v.7, p.389-398, 2006.

PEARSON, R.A.; OUASSAT, M. Estimation of the liveweight and body condition of working donkeys in Morocco. Vet. Rec., v.138, p.229-233, 1996.

SAMPAIO, B.F.B., SHIROMA, M.Y.M., BERTOZZO B.R. et al. Equilíbrio do casco equino. Rev. Electron. Vet., v.15, p.1-11, 2014.

SENIOR, J.M. Not small horses: improving treatments for donkeys. Vet. Rec., v.173, p.292-293, 2013.

STACHURSKA, A.; KOLSTRUNG, R.; PIETA, M.; SILMANOWICZ, P. Hoof size as related to body size in the horse (Equus caballus). Anim. Sci. Pap. Rep., v.29, p.213-222, 2011.

STASHAK, T.S. Claudicação em equinos segundo Adams. 5.ed, São Paulo: Roca, 2006. 1093p.

THOMASON, J.J. Variation in surface strain on the equine hoof wall at the midstep with shoeing, gait, substrate, direction of travel, and hoof shape. Equine Vet. J., v.30, supl.26, p.86-95, 1998.

TURNER, T.A. Examination of the equine foot. Vet. Clin. N. Am. Equine Pract., v.19, p.309-332, 2003.

TURNER, T.A. The use of hoof measurements for the objective assessment of hoof balance. ANNUAL CONVENTION OF THE AMERICAN ASSOCIATION OF EQUINE PRACTITIONERS, 38. Proceedings..., [s.1.]: AAEP, 1992. p.389-395, 1992. 